\title{
SATAPANG BEAUTY (PRODUK SABUN TALAS JEPANG/SATOIMO)
}

\section{Busthanul Nurbaya*, Jumriah Langkong., Anwar Hardiyanti, Nawir A. Fathanul, Khatimah Husnul, Sakia Nurul, Fadhilah Nur.}

\author{
NurbayaBusthanul \\ JurusanSosialEkonomiPertanian \\ FakultasPertanian, UniversitasHasanuddin \\ Jl. PerintisKemerdekaan Km-10, Makassar, Indonesia \\ E-mail: bayabusthan.uh82@gmail.com
}

\begin{abstract}
ABSTRAK
Talas Jepang Satoimo (Colocasia asculenta var. Antoquorum) merupakan tanaman baru dikembangkan dan dibudidayakan di Indonesia, khususnya di Sulawesi Selatan.. Talas Jepang (Satoimo) merupakan salah satu pangan pokok masyarakat Jepang yang kaya akan kandungan gizi berupa Kalori (92,30 kal); protein (2,38 gram); Lemak (0,17 grma); Karbohidrat (16,22 gram); Calsium (9,00 mg); Phospor (5,00 mg), Serat (16,18\%), mengandung Collagen yang tinggi., dan baik bagi kesehatan...Selain itu Talas Jepang dapat diolah menjadi berbagai macam produk, salah satunya produk sabun. Dengan berbekal pengetahuan dan kreativitas, mahasiswa terinspirasi untuk membuat sebuah unit usaha yang yang memproduksi sabun berbahan dasar talas jepang yang diharapkan dapat tumbuh dan berkembang. Masalahnya, bagaimana seorang mahasiswa dapat mengoptimalisasi bakat dan minat sebagai enterpreneur, membuka lapangan pekerjaan sehingga memahami dan memanfaatkan peluang pasar produk tersebut, mengetahui kebutuhan dasar masyarakat dengan menciptakan produk berkualitas dengan harga terjangkau. Dengan diciptakannya produk ini, diharapkan mampu memberikan manfaat kepada masyarakat secara umum dan secara khusus mahasiswa dapat menciptakan kinerja usaha terutama manfaat olahan Talas Jepang. Tujuan pembuatan usaha CV. Satoimo ini adalah : (1) membangun softskill atau karakter wirausaha; (2) menciptakan inovasi baru yang berbahan dasar Talas Jepang; (3) menciptakan produk sabun yang aman dari bahan kimia; (4) dapat menjadi solusi lapangan kerja bagi masyarakat. Karateristik talas jepang sebagai salah satu bahan dasar dalam pembuatan sabun natural kaya akan kandungan gizi dan nutrisi yang baik bagi kesehatan dan tubuh. Dapat disimpulkan bahwa memproduksi sabun berbahan dasar talas jepang memiliki nilai ekonomis sehingga sangat potensil untuk dikembangkan.
\end{abstract}

Kata Kunci :Satapang, Sabun, Talas Jepang.(Satoimo) 


\section{PENDAHULUAN}

\subsection{Latar Belakang}

Salah satu komoditi yang digalakkan di Indonesia, khususnya di Sulawesi Selatan adalah komoditi Talas Jepang yang dikenal dengan nama "Satoimo". Talas Jepang (Satoimo) adalah komoditi tanaman pangan yang bila dibudidayakan memberikan keuntungan yang menjanjikan dan memiliki kandungan gizi berupa Kalori $(92,30$ kal); protein (2,38 gram); Lemak $(0,17$ grma $) ; \quad$ Karbohidrat $(16,22$ gram); Calsium (9,00 mg); Phospor $(5,00 \mathrm{mg})$, Serat $(16,18 \%)$, dan mengandung Collagen yang tinggi (Yulian. At al. 2016). Satoimo atau yang lebih banyak kita kenal dengan nama talas jepang, merupakan jenis tanaman yang sangat menguntungkan baik dari segi kesehatan maupun secara ekonomi, karena tanaman talas jepang kaya akan kandungan karbohidrat, sehingga sangat baik bagi tubuh, dan juga dapat dijadikan sebagai salah satu bahan pokok pangan. Selain itu, harga jual dari tanaman satoimo juga terbilang cukup tinggi, jadi akan sangat menguntungkan jika dikembangbiakkan (Ameli, Dwika Dhanty., et al. 2016).

Di zaman sekarang, minat masyarakat terhadap kecantikan memiliki perhatian lebih, sehingga ada begitu banyak masyarakat yang rela mengeluarkan biaya lebih atau mahal, untuk terlihat cantik. Akan tetapi, kebanyakan masyarakat hanya mempertimbangkan hasil cantik atau tidaknya, tanpa memperdulikan aman tidaknya kosmetik yang mereka gunakan. Oleh sebab itu, kami berinisiatif untuk mengembangkan sebuah usaha berbasis kecantikan dengan menggunakan bahan dasar yang alami, yang tentunya akan lebih aman disbanding kosmetik dengan yang berbahan kimia. Adapun jenis produk yang akan kami buat adalah satapang, yang berbahan dasar talas jepang. Talas jepang merupakan salah satu bahan pokok yang baik digunakan karena kandungan kolagen yang tinggi pada talas jepang yang baik untuk kesehatan kulit (Rosdanelly, 2018)

Berdasarkan pernyataan diatas, maka Satapang hadir sebagai solusi 
bagi masyarakat, yang peduli pada kesehatan kulit, namun tidak perlu takut dengan bahan kimia yang banyak terkandung dalam produk kecantikan. Kandungan alami seperti kolagen yang tinggi pada tanaman talas jepang, sangat memungkinkan komoditi ini untuk diolah menjadi produk kecantkan tanpa tambahan bahan kimia yang berlebih (Astuti, 2017). Sehingga kami para pendiri usaha Satapang berinisiatif untuk mengikutkan usaha kami pada ajang penulisan karya ilmiah berbasis wirausaha, agar mendapat perhatian lebih dari pihak-pihak terkait, agar dapat memudahkan kelancaran produksi dari usaha kami.

\subsection{Tujuan}

Adapun tujuan dari program roti natural ini adalah :

1. Membangun softskill atau karakter wirausaha.

2. Menciptakan inovasi baru yang berbahan dasar talas jepang.

3. Menciptakan produk satapang yang aman dari bahan kimia.

4. Menjadi solusi lapangan pekerjaan bagi masyarakat terutama yang berjiwa wirausaha.

\subsection{Manfaat}

1. Dapat mengoptimalisasi bakat dan minat sebagai enterprenuer.

2. Dapat menciptakan kinerja usaha terutama manfaat dari talas jepang.

3. Mengetahui kebutuhan dasar masyarakat dengan menciptakan produk yang berkualitas dengan harga terjangkau.

4. Membuka lapangan pekerjaan sehingga memahami dan memanfaatkan peluang pasar produk tersebut.

\section{METODE PELAKSANAAN}

\subsection{Kapasitas Produksi}

Kapasitas produk dapat ditentukan dengan perhitungan penggunaan bahan baku. Adapun kapasitas produk yang direncanakan dalam satapang ini adalah 10 buah perhari dengan masa percobaan selama 3 bulan.

\subsection{Ketersediaan}

\section{Fasilitas/Sarana Produksi}

Fasilitas atau sarana produksi merupakan suatu teknologi yang dapat digunakan untuk memudahkan proses produksi suatu produk. Fasilitas atau sarana produksi yang 
digunakan pada produksi satapang ini terbilang cukup mudah untuk didapatkan serta harga yang terjangkau. Selain itu, tempat yang digunakan untuk proses produksi cukup luas sehingga memudahkan dalam proses pembuatan satapang.

\subsection{Ketersediaan Bahan Baku}

Bahan baku merupakan material atau bahan dasar yang diperlukan untuk membuat suatu produk secara menyeluruh. Bahan baku yang digunakan dalam proses satapang ini adalah talas jepang, larutan $\mathrm{NaCl}$, Aquades, tepung beras, Soda api, minyak zaitun, minyak kelapa, minyak goreng. Bahan tersebut dapat diperoleh dengan mudah di toko ataupun swalayan di Makassar

\subsection{Sumber Daya Manusia}

Usaha ini dirintis oleh beberapa mahasiswa yang terdiri dari background keilmuan yang berbeda. Hal ini bertujuan agar masingmasing bidang ilmunya dapat memberikan kontribusi dalam menjalankan usaha satapang dengan keahlian dan keterampilan yang dimiliki.

\section{HASIL DAN PEMBAHASAN}

\subsection{Deskripsi Usaha}

\subsubsection{Bidang Usaha} satapang dihadirkan sebagai usaha yang bergerak di bidang industri kecantikan. Usaha ini dirintis oleh mahasiswa yang berasal dari Universitas Hasanuddin. Alasan memilih usaha ini karena melihat peluang pada industri kecantikan yang dari waktu ke waktu semakin berkembang.

\subsubsection{Jenis Produk}

Produk yang dihasilkan satapang saat ini berfokus pada sabun yang terbuat dari bahan dasar berupa talas jepang, yang baik digunakan oleh semua kalangan usia, karena terbuat dari bahan dasar alami, dan tidak menggunakan bahan kimia yang dapat membahayakan kesehatan.

$$
\text { Adapun bahan yang }
$$
dibutuhkan dalam proses pembuatan satapang, yaitu sebagai berikut:

- Tepung/buah talas jepang 100 gr

- Minyak zaitun 100 gr

- Minyak kelapa 150 gr

- Minyak kepala sawit 150 gr

- $\mathrm{NaOH} 75 \mathrm{gr}$ 
- Aquades 145 gr

Untuk mendukung proses produksi satapang, digunakan peralatan sebagai berikut: Panci/baskom tebal, timbangan (gr), hand blender, spatula, cetakan, kertas anti air, handuk $30 \mathrm{Cm} \mathrm{X} 15 \mathrm{Cm}$, pisau, gunting dapat dilihat pada Gambar Lampiran 1.

\subsubsection{Kegunaan, Keunggulan,}

\section{Keunikan}

Satapang merupakan produk kecantikan berupa sabun yang baik dan aman untuk digunakan semua kalangan. Dengan mengutamakan kepuasan konsumen diharapkan produk ini diminati masyarakat, sehingga penjualannya terus meningkat yang pada akhirnya akan mendorong berkembangnya usaha. Karakteristik bahan baku utama berupa talas jepang, yang banyak dibudidayakan oleh petani saat ini karena tanaman tersebut kaya akan kandungan gizi dan nutrisi serta keuntungan penjualan yang juga menjanjikan bagi petani yang membudidayakan talas jepang.

Keunggulan dari bahan baku satoimo yaitu sebagai berikut:
1. Sebagai bahan pangan alternative yang mengandung protein dan kalori yang tinggi, tetapi memiliki kandungan karbohidrat yang tinggi dan gula yang rendah sehingga aman untuk dikonsumsi.

2. Memiliki nilai dan prospek ekonomi yang cukup bagus dan pasarnya ada

3. Dapat diolah menjadi beberapa macam olahan produk.

4. Bahan dasar pembuatan satapang menggunakan tepung talas jepang

\subsubsection{Lokasi Usaha}

Lokasi usaha sabun satoimo

yaitu di Jl. Rudal 13 Perumahan

Citra Daya Permai 1. Tempat tersebut cukup strategis untuk menjangkau target pasar usaha kami.

\subsubsection{Waktu}

Waktu produksi merupakan suatu kegiatan yang meliputi proses pengadaan bahan baku hingga produk laku terjual dan perusahaan memperoleh keuntungan. Satu siklus produksi sabun satoimo yaitu satu bulan. Pengadaan dan proses produksi sabun satoimo membutuhkan waktu satu hari. 
Dalam sehari diharapkan dapat memproduksi 10 buah sabun.

\subsection{Rencana Pemasaran}

Perencaan pemasaran (marketing planning) bentuk dari proses manajement yang mengarah pada strategi pemasaran dimana tujuan utamanya yaitu untuk mencapai tujuan pemasaran sehingga marketing plan dilakukan pada serangkaian proses yang sistematis melalui koordinasi untuk mendapatkan keputusan rencana pemasaran (Winahyu 2008).

\subsubsection{Target Pasar}

Perencanaan target pasar merupakan hal penting yang harus dilakukan. Perencanaan target pasar bertujuan untuk mengenal segmen pasar yang telah ditentukan dan merencanakan cara apa yang paling optimal agar segmen pasar memberikan kemungkinan paling besar untuk memnbeli produk yang dipasarkan. Target pasar untuk satapang sendiri yaitu remaja dan orang dewasa. Sebagai pemula, usaha ini dimulai dengan lingkungan terdekat yaitu mahasiswa Universitas Hasanuddin dan masyarakat sekitar.

\subsubsection{Wilayah Pemasaran}

Wilayah pemasaran produk satapang ini ialah di Kota Makassar, Sulawesi Selatan, khususnya pada daerah Tamalanrea dan wilayah kampus. Posisi pasar untuk produk kami ini akan jauh lebih menguntungkan karena tidak berpusat pada satu titik pemasaran saja. Selain itu, menjangkau perkotaan sehingga dapat menarik lebih banyak konsumen.

\subsubsection{Situasi Persaingan}

Persaingan antar produsen atau merk memang terjadi pada hampir semua struktur pasar produk.Untuk produk yang kami tawarkan, terdapat pesaing baik yang hampir serupa dari segi bentuk maupun yang memiliki sistem fungsi kurang lebih sama dengan produk kami. Adapun produk yang tidak sejenis namun dapat mensubstitusi fungsi dan nilai estetika dari produk kami.Namun, hadirnya Satapang lebih mengutamakan kualitas dan juga kebermanfaatan bagi tubuh serta harga yang terjangkau dari produk sabun yang sudah ada sebelumnya.

\subsubsection{Strategi Pemasaran}

Strategi pemasaran dari produk sabun satoimo ialah menetapkan 
harga yang relatif murah sehingga mudah dijangkau oleh semua kalangan masyarakat namun tetap memperhatikan keamanan. Adapun bentuk pemasaran produk satapang yaitu:

1) Promosi melalui komunikasi langsung kepada orang-orang disekitar dengan menanamkan citra positif terhadap produk yang ditawarkan seperti menceritakan keunggulan produk

2) Bekerja sama dengan mahasiswa melalui sistem reseller disetiap fakultas yang ada di Universitas Hasanuddin

3) Melakukan promosi diberbagi media online seperti facebook, line, whatsapp, dan instagram

4) Membagikan brosur yang dilengkapi dengan alamat produksi serta nomor telepon.

\subsubsection{Jumlah dan Harga Produk}

Produk yang kami tawarkan berupa sabun dengan bahan dasar talas jepang. Untuk konsumen langsung, produk ini kami jual dengan harga Rp. 25.000,-/kemasan
Jumlah produk yang kami harapkan dalam sehari sebanyak 10 kemasan.

\subsection{Rencana Produksi dan}

\section{Pengembangan Produk}

Rencana pengembangan bisnis kedepannya dimulai dari pengembangan produk, yakni menghasilkan produk-produk baru seperti lulur dan masker namun tetap menggunakan talas jepang. Selanjutnya pengembangan wilayah pemasaran akan terus dilakukan agar menjangkau seluruh konsumen. Contohnya dengan membuka outlet serta memperluas reseller mahasiswa bukan hanya di kampus Unhas melainkan menjangkau setiap Universitas yang ada di Makassar.

Untuk menghasilkan produk yang berkualitas dan berdaya saing kuat, kualitas bahan baku dan proses produksinya sangat menentukan. Oleh sebab itu dalam rangka peningkatan produksi dan pengembangan produk, perusahaan akan melakukan langkah-langkah sebagai berikut:

1. Meningkatkan kapasitas pemasaran melalui perluasan jaringan online 
2. Meningkatkan ketersediaan bahan baku yang berkualitas terutama bahan baku talas jepang dan harganya terjangkau

3. Meningkatkan daya saing melalui daya tarik konsumen yaitu memperhatikan keunggulan dari aspek kandungan kolagen dan penggunaan kosmetik tanpa bahan kimia.

\section{SIMPULAN}

Satapang merupakan usaha yang bergerak di bidang industri kecantikan. Produk yang dihasilkan satapang saat ini berfokus pada sabun yang terbuat dari bahan dasar talas jepang. Satapang sangat aman digunakan karena terbuat dari bahan alami yang kaya dengan kandungan nutrisi di dalamnya. Adapun harga produk satapang yang ditawarkan cukup terjangkau dikalangan masyarakat. Usaha ini diharapkan dapat meningkatkan kesejahteraan masyarakat dan mengurangi angka pengangguran yaitu sebagai penyedia lapangan pekerjaan.

\section{DAFTAR PUSTAKA}

Amelia, Dwika Dhanty., et al. 2016. Analisis Usahatani Talas Satoimo (Colocasia esculenta var. antiqourum) (Studi Kasus: di Desa Suka Sari Kecamatan Kabawetan Kabupaten Kepahiang). Program Studi Agribisnis: Universitas Dehasen Bengkulu.

Astuti. 2017. Karakteristik Tepung Talas Varietas Bentul dan Satoimo Hasil Fermentasi Terkendali dengan Inokulum Komersial. Fakultas Pertanian: Institut Pertanian Bogor

Rosdanelly. $2018 . \quad$ Prospek Pengembangan Talas Jepang (Colocasia Esculenta Var Antiquorum) Di Balai Diklat Pertanian (BPD) Saree, Aceh Besar. Pertanian: Jurnal Ilmiah Mahasiswa (JIM).

Yulian, Dkk. 2016. Pertumbuhan Vegetatif Talas Satoimo dan Kultivar Lokal pada Dosis Pupuk Nitrogen yang Berbeda. Program Studi Agroteknologi: Universitas Bengkulu.

Winahyu, Mukti. Et al. 2008. Perencanaan Strategi Pemasaran Dalam Peluncur Produk Baru dengan Merek "Exo Coffe" pada PT. JamuPuspo Internusa. Kebayoran: Jakarta Selatan 


\section{IFINM}

Prosiding PKM-CSR, Vol. 2 (2019)

e-ISSN: 2655-3570

\section{LAMPIRAN 1}
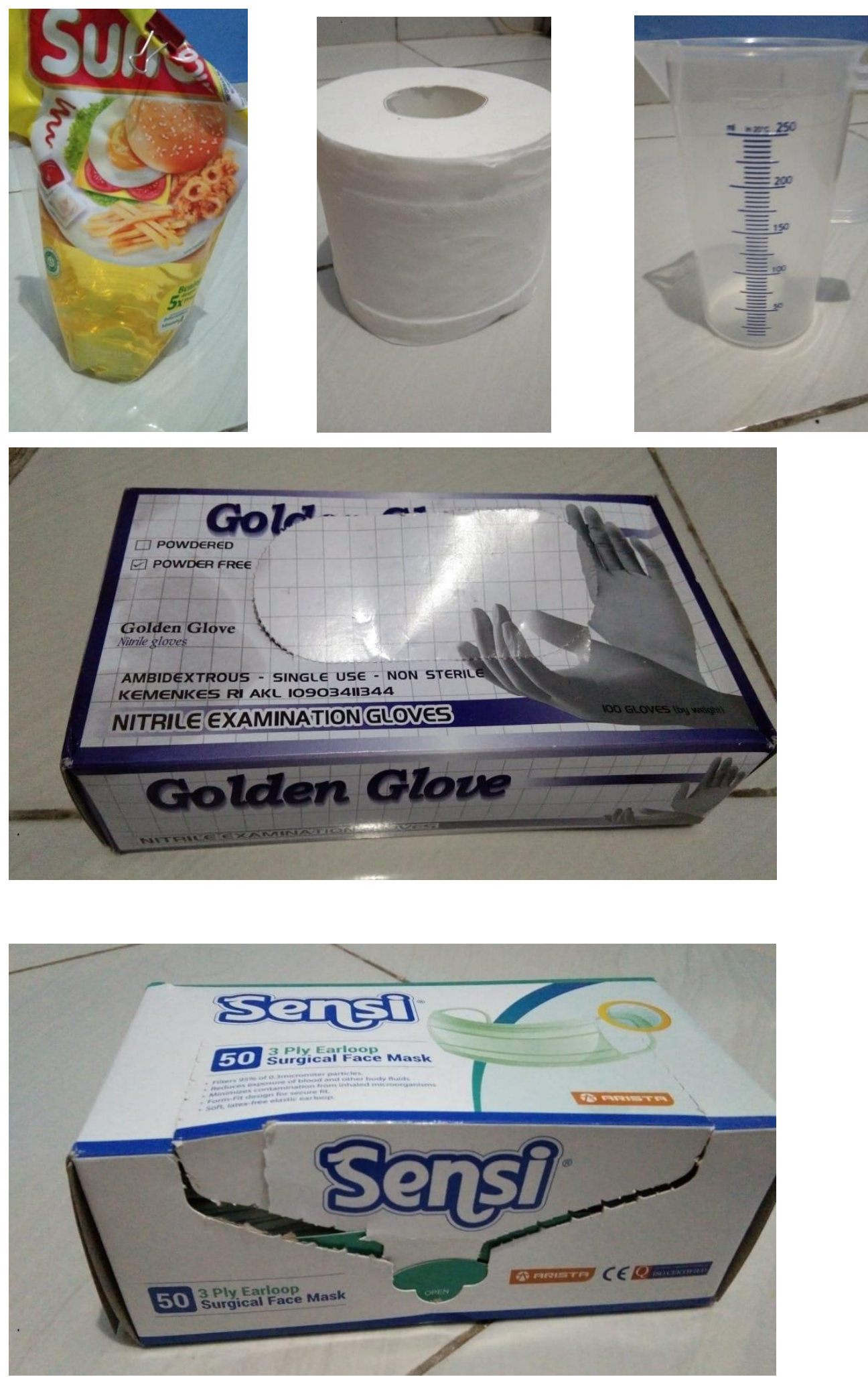

Ekonomi, Sosial, dan Budaya 


\section{IFINM}

Prosiding PKM-CSR, Vol. 2 (2019)

e-ISSN: 2655-3570
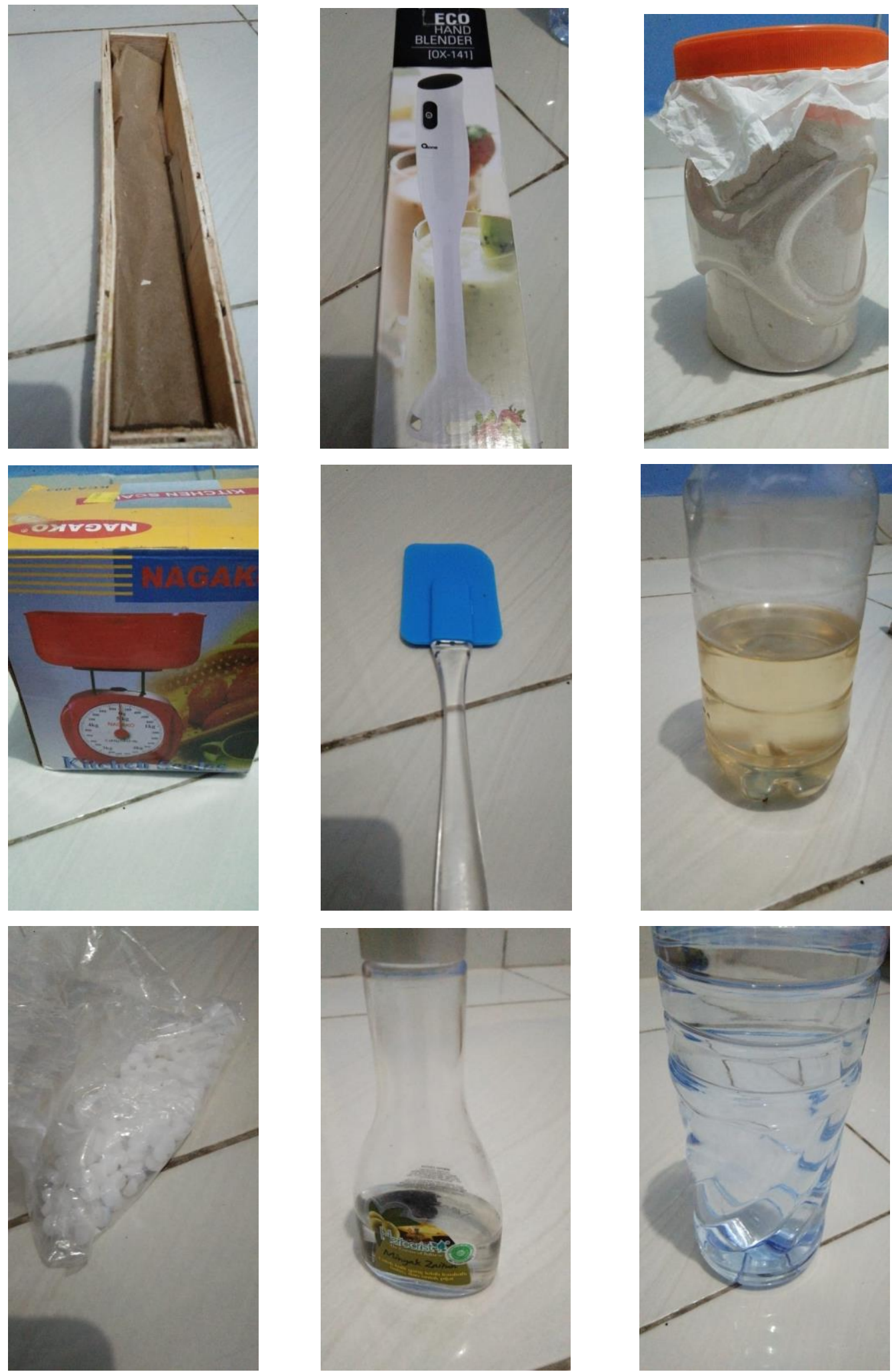

Ekonomi, Sosial, dan Budaya 


\section{IFKM
CISBI}

Prosiding PKM-CSR, Vol. 2 (2019)

e-ISSN: 2655-3570

\section{LAMPIRAN 2}
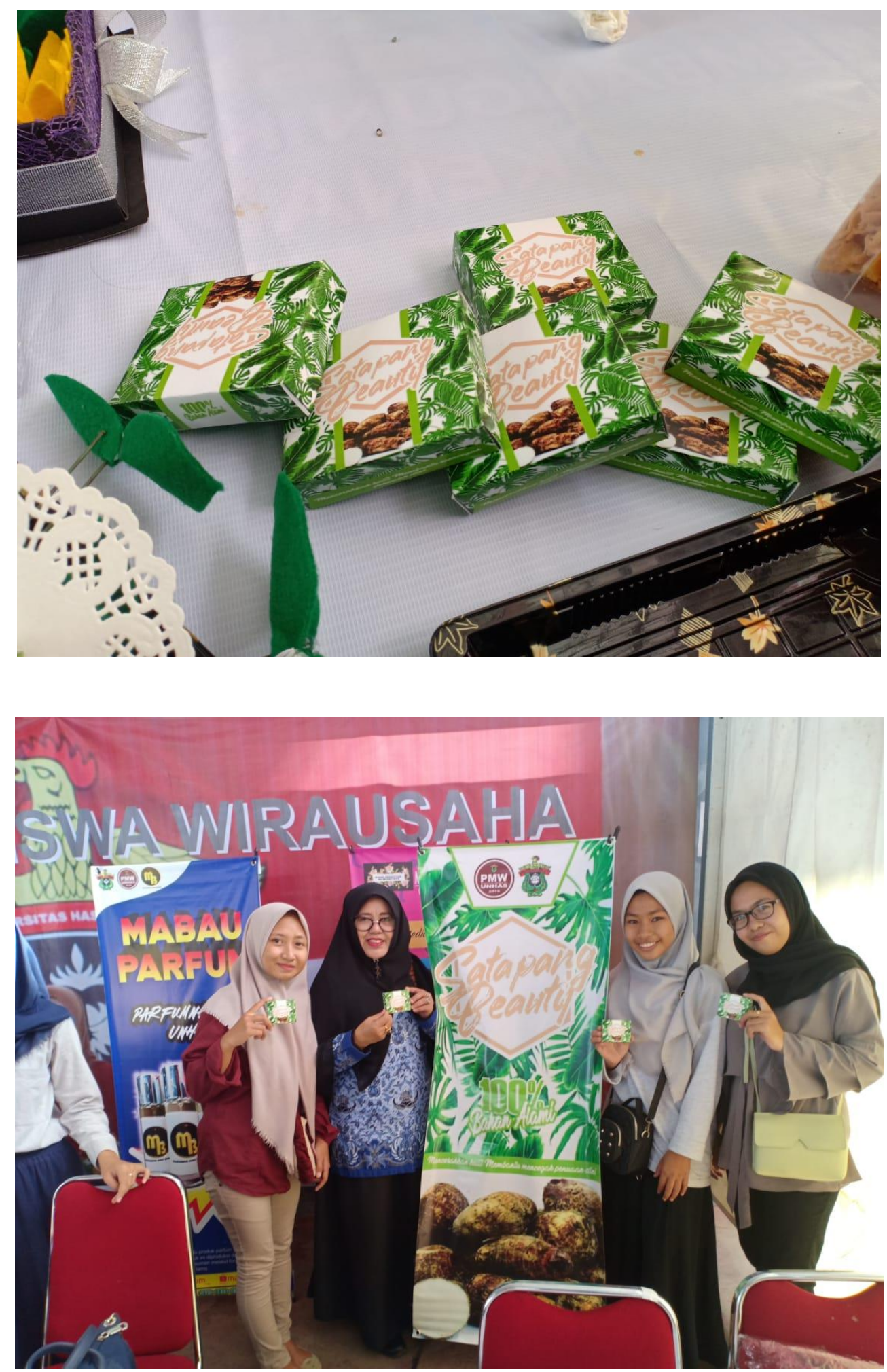

\begin{tabular}{l|l} 
Ekonomi, Sosial, dan Budaya & 1537
\end{tabular} 


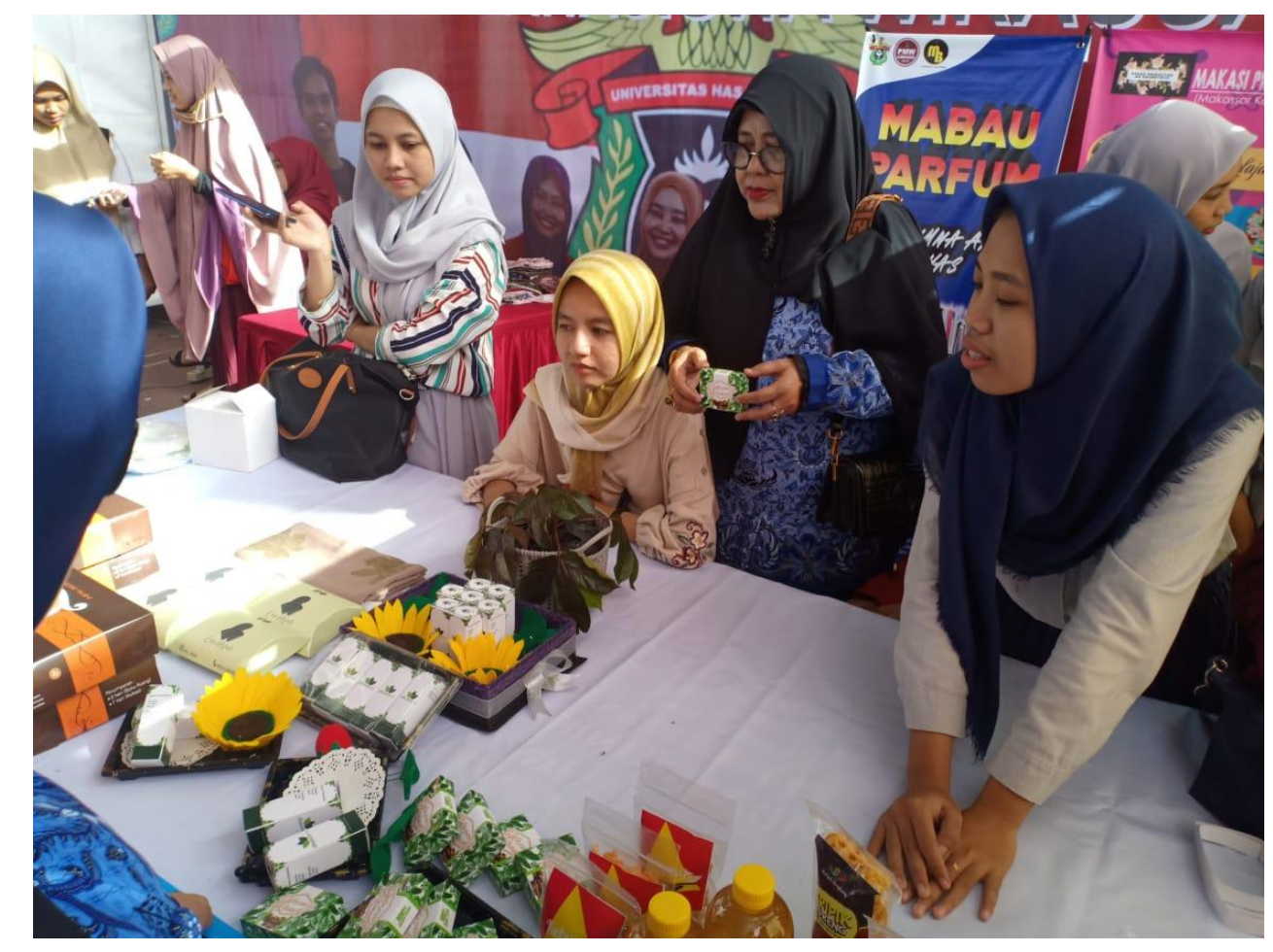

Ekonomi, Sosial, dan Budaya 1538 